\title{
PETROGENESIS OF MIDDLE PROTEROZOIC MAFIC DYKES IN THE SÃO FRANCISCO CRATON, BRAZIL: IMPLICATIONS FOR A FOSSIL MANTLE PLUME BENEATH THE NORTHERN ESPINHAÇO RANGE*
}

The geochemistry of mafic rocks in continental areas may provide valuable information regarding regional geologic evolution if the nature of the processes involved in their genesis is reasonably well constrained. It is of general acceptance that intracontinental mafic dykes and flood basalts usually carry the geochemical fingerprints of ocean flood basalts (MORB) and the continental crust (LGHTFOOT \& HAWKESWORTH, 1988; DUPUY et al., 1988; HERGT et al., 1989), possibly as the result of the growth and development of the sub-continental lithospheric mantle, from which some of them derive, or through MORB contamination and mixing with continental material. Sometimes asthenospheric MORB-like magmas can reach the Earth's surface without being too much contaminated by the continental lithosphere as is possibly the situation of most of the Deccan basalts (LIGHTFOOT \& HAWKESWORTH, 1988). In other situations lithospheric mantle sources must be considered, such as in the case of the Paraná high-phosphorus, high-titanium basalts (MANTOVANI et al., 1985; HAWKESWORTH et al., 1988). The heat sources required for mantle partial melting is a matter of dispute, but decompression beneath stretched continental or oceanic crust and the rise of hot mantle plumes are usually invoked. Studies of basaltic rocks from the ocean basins have shown that magmatism associated with mantle plume or hotspots is dominantly alkaline and enriched in highly incompatible trace elements (e.g. LeROEX et al., 1983, 1985; HALLIDAY et al., 1990). Alkaline compositions can also result through low degree of melting of depleted asthenospheric mantle sources (FITTON \& DUNLOP, 1985).

\footnotetext{
With support from CNPq (Brazil) and CVCP (U.K.)

'Instituto de Geociências, UNICAMP, 13081, Campinas, SP, Brazil.
} 
Here, I report geochemical data on mafic dykes from the Pará de Minas area, Minas Gerais, and the Curaçá River Valley, Bahia, which may be interpreted as of lithospheric and asthenospheric origin, respectively. The emplacement of these dykes is likely to be related to the development of the Middle Proterozoic Espinhaço-Chapada Diamantina rift system (Fig. 1).

The Curaçá dykes are ophitic-textured, fine- to medium-grained rocks composed of plagioclase and clinopyroxene, with accessory sulphide, oxide, apatite and alkalifeldspar. Vesicular structure is not uncommon at dyke margins, nor are sericite and carbonate as post-emplacement fracture-fillings. No feldspatoid mineral has been observed. The dykes exhibit internal chemical variation characterized by enrichment in incompatible trace elements from the centre towards the margins of the dykes. Margin samples are generally more REE-fractionated than those from the centre. Geochemical modelling suggests that processes such as crustal contamination, thermal erosion, flow differentiation, post-emplacement alteration or high-pressure fractional crystallization cannot satisfactorily explain the observed intra-dyke chemical variation. An alternative model is put foward, whereby the dykes have been extracted from zoned magma chambers possibly coupled with different extents of melting of a garnet-bearing mantle source. The presence of amygdaloidal texture confined to

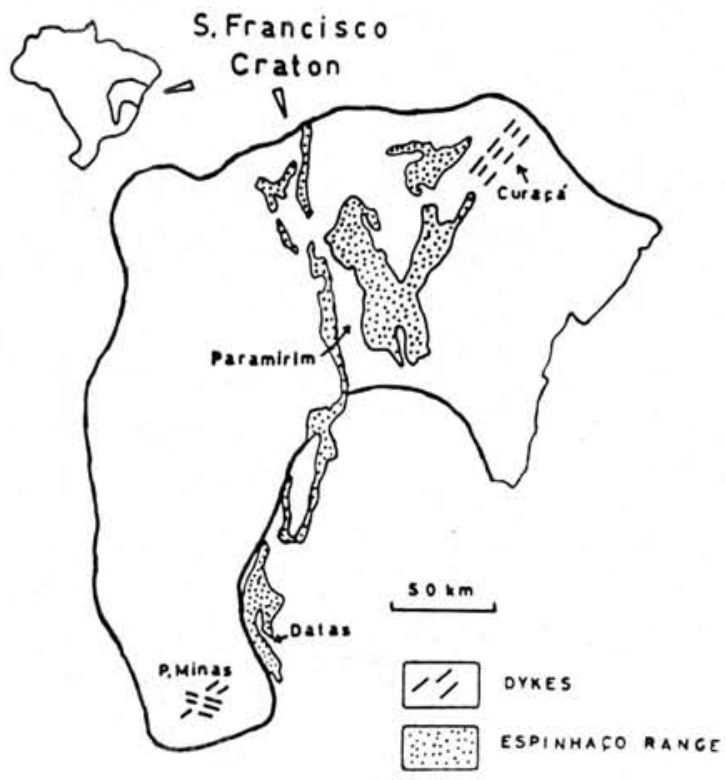

Figure 1 - Locality map showing the São Francisco craton, the Espinhaço range, and the mafic dykes of Curaçá and Pará de Minas. 
dyke margins as well as highly fractioned REE patterns in all dykes and cross-cutting HREE patterns in others seem to support the model. The dykes from Pará de Minas are geochemically distinct from the Curaçá dykes and are composed of plagioclase, clinopyroxene, metamorphic amphibole, and accessory apatite, oxides and quartz alkalifeldspar micrographic intergrowth.

The dykes may be divided into two geochemical groups on the basis of REE fractionation and other trace element abundances, such as $\mathrm{Ba}$ and $\mathrm{Sr}$. Theoretically, these two groups cannot be related to each other by fractional crystallization or different extents of melting from a common mantle source. The low barium, low strontium group ( $\mathrm{LBaSr}$ ) is likely to have originated from a more refractory source and the high barium, high strontium group ( $\mathrm{HBaSr}$ ) from an incompatible element enriched source. Intra-group geochemistry can be interpreted readily in terms of various extents of melting and fractional crystallization of olivine, pyroxene, plagioclase and $\mathrm{Fe}-\mathrm{Ti}$ oxides. The age relationship between these two compositionally distinct groups is yet unclear.

Figure 2a shows primitive mantle-normalized multi-element diagrams (normalizing values from SUN \& MCDONOUGH, 1989) of basalts from ocean-island (OIB, SUN \& McDONOUGH, 1989), intra-oceanic arc (IAT, sample AN8 of WOODHEAD, 1989), mid-ocean ridge (N-MORB, sample All-53-12 of LeROEX et al., 1983), as well as average values for Deccan (Deccan-A, M, PA, LIGHTFOOT \& HAWKESWORTH, 1988) and high-phosphorus, high-titanium Paraná continental flood basalts (HPT, MANTOVANI et al., 1985; HAWKESWORTH et al., 1988). As shown, the Deccan basalts and N-MORB display similar patterns for the high-field strength element part of the diagram ( $\mathrm{Nb}, \mathrm{P}, \mathrm{Zr}, \mathrm{Ti}$ and $\mathrm{Y}$ ), the former at higher abundances than the latter. Island-arc tholeiites are characterized by enrichment of ULE and depletion of high-field strength elements relative to N-MORB. On the other hand, the Paraná basalts (HPT), which are believed to have originated from an enriched lithospheric mantle source (cf. MANTOVANI et al., 1985; HAWKESWORTH et al., 1988), display a more fractionated pattern with a marked negative anomaly, a characteristic of subduction environment. The Paraná HPT basalts and OIB exhibit similar patterns, especially from La to $Y$, but differ significantly with respect to the $\mathrm{Nb}$ anomaly (positive in OIB) and trace element ratios such as $\mathrm{Ba} / \mathrm{Nb}, \mathrm{K} / \mathrm{Nb}, \mathrm{Nb} / \mathrm{La}, \mathrm{Zr} / \mathrm{Y}, \mathrm{Zr} / \mathrm{Nb}$, and $\mathrm{Y} / \mathrm{Nb}$. These trace element ratios are likely to reflect their mantle source ratios as theoretical modelling of incompatible trace element behaviour during partial melting and fractional crystallization reveals little variation, except as very low degrees of melting $(<5 \%)$ for ratios between elements with similar distribution coefficient $(\mathrm{Kd})$.

Figure $2 \mathrm{~b}$ presents data for average compositions of the Curaçá, and Pará de Minas dykes, whereas in Figure $2 \mathrm{c}$ all available data for basaltic rocks intrusive into or related to the southern Espinhaço range are shown (data from HOPPE et al., 1983). The similarity between the MORB-like 


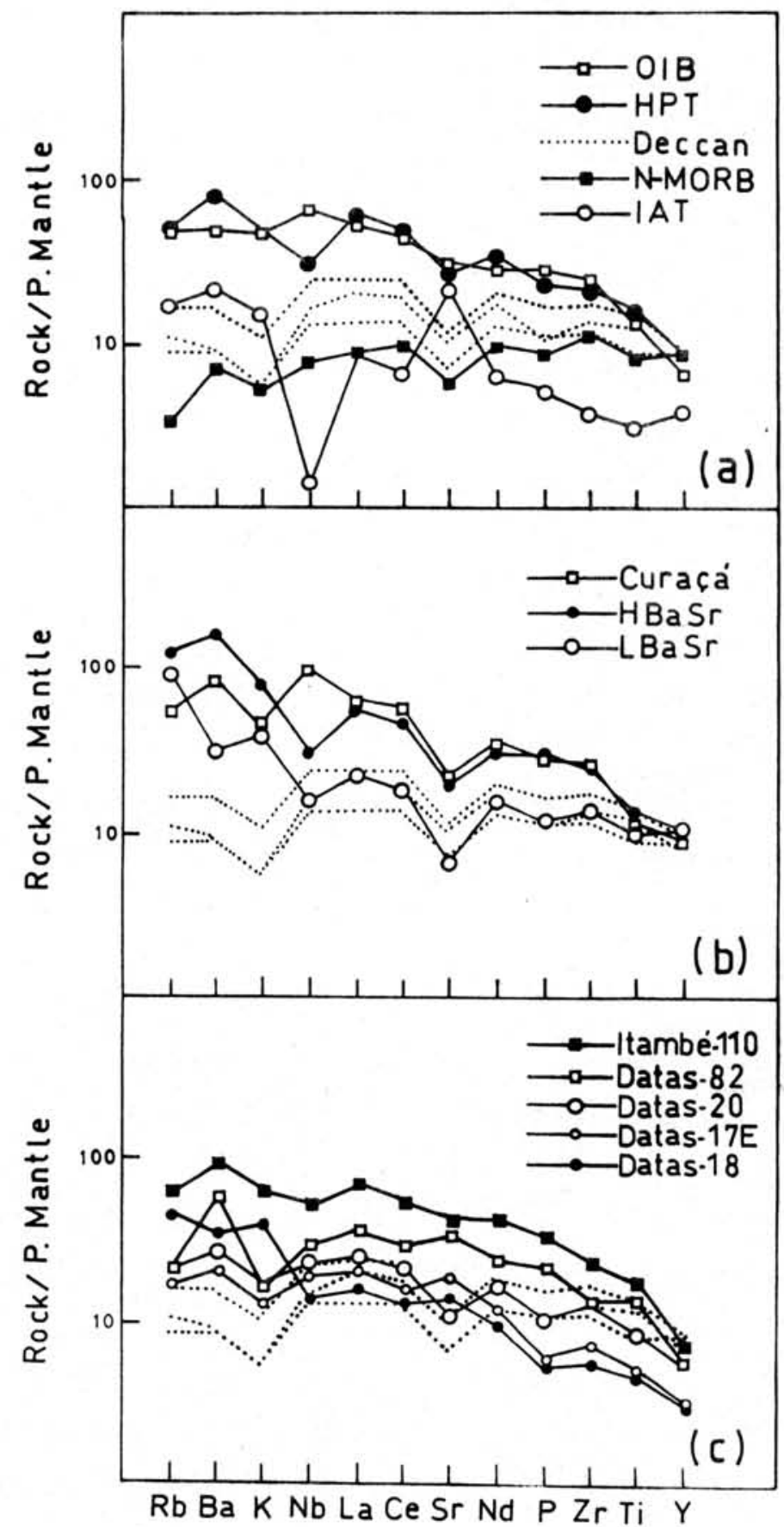

Figure 2 - Multi-element diagrams for average compositions of Curaçá and Pará de Minas mafic dykes compared with published data for Deccan flood basalts (averages), ocean-island basalts (OIB), intra-oceanic arc basalts (LAT), mid-ocean ridge basalts (N-MORB), as well as high-phosphorous, high-titanium Paraná continental flood basalts (HPT). For references, see text. 
Deccan basalts and the Pará de Minas LBaSr dykes, is readily apparent especially from $\mathrm{Nb}$ to $\mathrm{Y}$ which are thought to be less mobile than $\mathrm{Rb}, \mathrm{Ba}$ and $\mathrm{K}$ during alteration and metamorphism. The Para de Minas $\mathrm{HBaSr}$ group is more fractionated and exhibits a strong negative $\mathrm{Nb}$ anomaiy characteristic of subduction-related magmas. The Curaçá dykes, on the other hand, display fractionated patterns too but have a marked positive $\mathrm{Nb}$ anomaly like ocean island basalts. All these features lead to the following conclusions: (i) the Curaçá dykes may have originated from asthenospheric mantle sources with geochemical characteristics similar to ocean island basalts of the HIMU- (e.g. St. Helena) and EMtypes (e.g. Tristan da Cunha) (see ZINDLER \& HART, 1986; WEAVER et al., 1987); (ii) the Para de Minas dykes are likely to have been derived from lithospheric mantle sources enriched in low-field strength elements.

It is suggested that the origin of the Curaça dykes is probably related to a Middle Proterozoic hotspot (or thermal anomaly) responsible for, or developed during, the evolution of the northern part of the Espinhaço rift. Divergent paleocurrents in sediments on both sides of the Paramirim block (SÁ, 1981), coupled with the occurrence of peralkaline acid volcanics (McREATH et al., 1981) and the NE direction of the Curaçá dykes (Fig. 1), suggest that the thermal anomaly is likely to have been located beneath the Paramirim block. The Curaçá dykes may thus represent the roots of an aulacogen and the Espinhaço range the collisional orogen. Additional studies are needed in the Paramirim area, especially on paleocurrent directions of Espinhaço-Chapada Diamantina sediments, gravity and seismic modelling, and heat flow to constrain any relics of mantle upwelling or basalt underplating. Also, studies of magma flow trajectories in the Curaçá dykes and U/Pb dating of zircons and /or baddeleite are required for a better understanding of the model. Although the alkaline volcanics/plutonics of the Paramirim area (McREATH et al., 1981; MARUEJOL et al., 1987) may have resulted from the interaction between an asthenospheric (or plume) source, possibly similar to that of the Curaçá dykes, and a crustal component, as is often invoked in the genesis of anorogenic granites (e.g. WHALEN et al., 1987), geochemical modelling for mixing, taking the composition of the Curaçá dykes or of a more MORB-like composition such as those of mafic rocks from the southern Espinhaço (HOPPE et al., 1983) as one end member and the lower crust or average crust (WEAVER \& TARNEY, 1984) as the other end member, fails to give a reasonable result for the generation of all subalkaline to peralkaline rocks of the Paramirim area. This observation is still open to further research and cannot be used solely as an argument to rule out the hotspot model. On the contrary, the presence of Nb-rich gabbros (I.McREATH, personal commun. Nov. 1990) and Nb-rich anorogenic granites and orthogneisses in the Paramirim area (MARUEJOL et al., 1987; CABY \& ARTHAUD, 1987) further suggests the possible influence of a hotspot beneath the above mentioned area. 
The mantle source of the Pará de Minas dykes, on the other hand, appears to have undergone extensive metasomatism in a scenario similar to that of present day island-arcs, although this environment may not necessarily have existed in the area. If this reasoning is correct such enrichment must have occurred before the Brasiliano collisional event that affected the Espinhaço rift as the dykes are overlain by Late Proterozoic Bambui metasediments. Samples from Datas and Itambé (Fig. 2c) are clearly diverse, the available data not being sufficient to understand the processes involved in their genesis. Nevertheless, their mantle-normalized multi-element patterns suggest similarities with MORB (Datas-20) and enriched lithospheric sources (Itambé-110). Additionally, the high-field element depletion of some samples relative to MORB (Datas-17E, 18), combined with their positive strontium anomalies, indicates some processes associated with subduction environment. A detailed geochemical study of these rocks is thus necessary to clarify these points.

As a concluding remark, I should emphasize that the geochemical comparison between mafic rocks associated with the Espinhaço-Chapada Diamantina rift system is very important in understanding the part that Proterozoic mantle plumes may have played in the disruption of the São Francisco craton and in the concentration of anomalous abundances of uranium and other incompatible elements in the Paramirim area. Moreover, the data summarized here and those presented by HOPPE et al. (1983) clearly anticipate the involvement of a great diversity of processes and sources in the genesis of the mafic rocks; the systematic geochemical and geochronological study of which, combined with other geological information, will certainly provide a better picture of the MidProterozoic evolution of South America with implications regarding questions such as the genesis of anorogenic granitic magmatism (e.g. the Paramirim granites in Bahia and Uatumã granites in Amazon region) and the polycyclic versus monocyclic controversy. No isolated geochemical information is sufficient to constrain the tectonic settings of basaltic magmatism in continental areas. The ultimate geochemical signature will depend on several factors, such as fractional crystallization, crustal contamination, mixing and mantle sources. The poor comprehension of such unknowns may result in misleading conclusions regarding regional evolution. Such may be the case of the Orós monocyclic belt in northeastern Brazil where the island-arc-like geochemical signature of Early Proterozoic anorogenic basic rocks has been invoked as a relic of an early orogenic event (SÁ et al., 1990). A similar signature is well documented on crustally contaminated Mesozoic low-titanium, lowphosphorous basalts of the Paraná basin (MANTOVANI et al., 1985) which are indisputably anorogenic.

\section{REFERENCES}


CABY, R. \& ARTHAUD, M. (1987) Petrostructural evolution of the Lagoa Real subalkaline metaplutonic complex (Bahia, Brazil). Revista Brasileira de Geociências, 17(4):636.

DUPUY, C.; MARSH, J.D.; MICHARD, A.; TESTA, S. (1988) Asthenospheric and lithospheric sources for Mesozolc dolerites from Liberia (Africa): trace element and isotope evidence. Earth and Planetary Sclence Letters, 87:100-110.

FITTON, J.G. \& DUNLOP, H.M. (1985) The Cameroon line, West Africa, and its bearing on the origin of oceanic and continental alkali basalt. Earth and Planetary Science Letters, 72:23-38.

HALUDAY, A.N.; DAVIDSON, J.P.; HOLDEN, P.: De WOLF, C.; LEE, D.C.; FITTON, J.G. (1990) Trace-element fractionation in plumes and the origin of HIMU mantle beneath the Cameroon line. Nature, 347:523-528.

HAWKESWORTH, C.J.; MANTOVANI, M.S.M.; PEATE, D. (1988) Lithosphere remobilization during Paraná CFB magmatism. Journal of Petrology. Special Lithosphere Issue, p.205-223.

HERGT, J.M.; CHAPPELL, B.W.; McCULLOCH, M.T.; McDOUGALL, I.; CHIVAS, A.R. (1989) Geochemical and isotopic constraints on the origin of the Jurassic dolerites of Tasmania. Journal of Petrology, 30:841-883.

HOPPE, A.; HORMANN, P.K.; EULERT, M.H. (1983) Padrões de terras raras de rochas básicas proterozóicas da Serra do Espinhaço-MG. In: SIMPÓSIO DE GEOLOGIA DE MINAS GERAIS, 2., Belo Horizonte, 1983. Anais. Belo Horizonte, SBG. Boletim, 3, p.143-148.

LeROEX, A.P. (1987) Source regions of Mid-Ocean Ridge Basalts: evidence for enrichment processes. In: MENZIES, M.A. \& HAWKESWORTH, C.J. (eds.) Mantle Metasomatism. London, Academic Press. p.389-422.

LOROEX, A.P.; DICK, H.J.B.; ERLANK, A.J.; REID, A.M.; FREY, F.A.; HART, S.R. (1983) Geochemistry, mineralogy and petrogenesis of lavas erupted along the Southwest Indian Ridge between the Bouvet triple junction and 11 degrees East. Journal of Petrology, 24(3):267-318. 
LeROEX, A.P.; DICK, H.J.B.; REID, A.M.; FREY, F.A.; ERLANK, A.J.; HART, S.R. (1985) Petrology and geochemistry of basalts from the American-Antartic ridge, Southern Ocean: implications from the westward influence of the Bouvet mantle plume. Contributions Mineralogy Petrology, 90:367-380.

UGHTFOOT, P. \& HAWKESWORTH, C.J. (1988) Origin of Deccan trap lavas: evidence from combined trace element and $\mathrm{Sr}, \mathrm{Nd}$ and $\mathrm{Pb}$ isotope studies. Earth Planetary Science Letters, 91:89-104.

MANTOVANI, M.S.M.; MARQUES, LS.; SOUSA, M.A.; CIVETTA, L; ATALLA, I.; INNOCENTI, F. (1985) Trace element and strontium isotope constaints on the origin and evolution of Paraná continental flood basalts of Santa Catarina State (Southern Brazil). Journal Petrology, 26:187-209.

MARUEJOL, P.; CUNEY, M.; FUZIKAWA, K.; NETTO, A.M.; POTY, B. (1987) The Lagoa Real subalkaline granitic complex (south Bahia, Brazil): a source for uranium mineralizations associated with Na-Ca metasomatism. Revista Brasileira de Geociências, 17(4):578-594.

McREATH, I.; SÁ, E.F.J.; FRYER, B.J. (1981) As vulcânicas ácidas proterozóicas da região da bacia do Rio Paramirim - Bahia. In: INDA, H.A.V.; MARINHO, M.M.; DUARTE, F.B. (eds.) Geologia e Recursos Minerais do Estado da Bahia: textos básicos. Salvador, CPM. V.4, p.121-134.

SÁ, E.F.J. (1981) A Chapada Diamantina e a faixa Santo Onofre: um exemplo de tectônica intraplaca no Proterozóico Médio do Cráton do São Francisco. In: INDA, H.A.V.; MARINHO, M.M.; DUARTE, F.B. (eds.) Geologia e Recursos Minerais do Estado da Bahia: textos básicos. Salvador, CPM. V.4, p.111-120.

SÁ, J.M.; LETERRIER, J.; BERTRAND, J.M. (1990) Petrologia e evolução geodinâmica da faixa Orós: evidências de uma bacia tardi-transamazônica. In: CONGRESSO BRASILEIRO DE GEOLOGIA, 36., Natal, 1990. Boletim de Resumos, Natal, SBG. p.300-301.

SUN, S.S. \& MCDONOUGH, W.F. (1989) Chemical and isotopic systematics of oceanic basalts: implications for mantle composition and processes. In: SAUNDERS, A.D. \& NORRY, M.J. (eds.) Magmatism in the ocean basins. Oxford. Geological Society by Blackwell Scientific. p.313-345 (Geological Society Special Publication, 42) 
WEAVER, B.L. \& TARNEY, J. (1984) Empirical approach to estimating the composition of the continental crust. Nature, 310:575-577.

WEAVER, B.L; WOOD, D.A.; TARNEY, J.; JORON, J.L (1987) Geochemistry of ocean island basalts from the South Atlantic: Ascension, Bouvet, St. Helena, Gough and Tristan da Cunha. In: FITTON, J.G. \& UPTON, B.G. (eds.) Alkaline igneous rocks. Oxford, Geological Society by Blackwell Scientific. p.253-267. (Geological Society Special Publication, 30)

WHALEN, J.B.; CURRIE, K.L; CHAPPEL, B.W. (1987) A type granites: geochemical characteristics, discrimination and petrogenesis. Contributions Mineralogy Petrology, 95:407-419.

WOODHEAD, J.D. (1989) Geochemistry of the Mariana arc (Western Pacific): source composition and processes. Chemical Geology, 76:1-24.

ZINDLER, A. \& HART, S. (1986) Chemical geodynamics. Annual Reviews of Earth and Planetary Sciences, 14:493-571. 